\title{
Individual counseling to argue in social media
}

\author{
Erwin Erlangga*) \\ Fakultas Psikologi Universitas Semarang \\ *) Corresponding author, $\equiv$ e-mail: erwinerlangga@usm.ac.id
}

\begin{abstract}
The purpose of this study is to improve students' argumentation skills in social media. The subjects were 20 students who were divided into two groups: the control group consisting of 10 people and the experimental group consisting of 10 people. The technique used was an quasi experiment with 10 interventions using individualized counseling services to the control group and experimental group. Based on the quasi experimental results by giving counseling to 20 students 10 times and analyzed, students' argumentation skill level increased after individual counseling. Shown with change of skill level of argumentation before treatment (preliminary evaluation) and after (final evaluation) as much as 90 points and through test using test with significance level $5 \%$ show $\mathrm{t}$ count $=7.077>\mathrm{t}$ table $=$ 2,179 . Based on the results of these calculations, show that the hypothesis mentions individual counseling affect students' argumentation skills can be accepted.
\end{abstract}

Keywords: Argument Skills, Social Media, Individual Counseling

How to Cite: Erlangga, E. (2017). Individual counseling to argue in social media. Couns-Edu: International Journal of Counseling and Education, 2(1): pp. 35-41. DOI: 10.23916/002017023810

\section{Introduction}

In the case of individual beings the individual creatures of social beings, as social beings, individuals must communicate with each other in everyday life. Other individuals can understand what he thinks, what he feels, and what he wants. In today's communicating activities, more people use social media as a means to argue express opinions, but sometimes not everyone can argue well in social media that cause problems to themselves, society and country (Katz, J., Capron, A. M., \& Glass, E. S., 1972). Mentioned that the skill of argument is important for human life so that human beings can establish the relationship of environment (Bronfenbrenner ,U. 2005). Argumentation skills are part of the adaptation of the environment so that humans need it as a condition for life, In this era of arguing skills is very important to establish communication with others. Communication can make a relationship warm and produce something positive. If the skill of argument is bad then the relationship between humans will be destroyed and the state will collapse (Andrews, F. M., \& Withey, S. B., 2012).

Children need a control in expressing opinions, because children are in the process of developments that always try, sometimes children imitate friends and even parents in communicating with the community (Keyes, C. L. M., 1998). As social beings, individuals must communicate with each other in everyday life. Other people can understand what he's thinking, what he was feeling and what he wants. In today's communication activities, more people are using social media as a means to argue express his opinion, but sometimes not everyone can argue well in the social media causing problems with the self, 
society and the state. In Circular Kapolri SE/06/X/2015 of article 28, paragraph 2, which reads "any person intentionally and without right to disseminate information intended to cause hatred or hostility individual and / or a particular group of people based on ethnicity, religion, race and intergroup (SARA). "and article 45 paragraph (2):" (2) every person who meets the elements referred to in article 28 paragraph (1) or subsection (2) shall be punished with imprisonment of six (6) years and / or a fine of $1,000,000,000.00$ (one billion rupiah). "I'm 1000 percent agree with the SE of hate speech. I love baseball too far freedom of expression. Cook the people say anything goes in social media. It's a lot of NGOs (nongovernmental organizations), people press ultraliberal translating democracy is freedom of speech, it's nonsense, "said Tjipta (Weston 2007). In the book (Weston 2007) 'argued' means provides a reason or evidence to support a conclusion. An argument is not only a statement about a particular view, and not merely just a disagreement. The argument is an attempt to support a particular view with reasons.

Another opinion is also spoken by (Keraf, 1981) that "argument is a form of rhetoric that seeks to influence the attitudes and opinions of others, that they believe and finally act in accordance with what is desired by the author or communicator". So in essence, argued a couple of facts in such a way so as to indicate whether an opinion or a certain thing is true or not is poured orally, while the ability to argue is the ability to influence the attitudes and opinions of others, so that the listener believes and ultimately act according to what is desired by the communicator. Argument is an attempt to find out which view is better than the other. Arguing is a way to explain and defend it by giving reasons and evidence that another person or listener could prepare the mind for yourself. To be able to argue well, a communicator in addition to having to explain the reasons and evidence to strengthen the establishment or opinions expressed, and understand what to talk about, what to say, and how to talk about it, the communicator must also have the courage and conveys regularly arguments submitted in accordance with applicable regulations. Skills argue still considered difficult by students. The difficulty of this argument is reflected in students' ignorance about the ethics of argumentation in social media, the phenomenon of what was discussed, and how appropriate to talk about the phenomenon. This is reinforced by the results of research that found that individual counseling is effective in increasing confidence in children broken home (Arfitriani, Y. N. 2010). Confidence is the basis of communication skills of social media

Meanwhile, the study argues in social media held less emphasis on training (practice) argued. Even if there workout activity was less effective and engaging for students. In addition, it has not been consistent and comprehensive activities to hone skills of argumentation in social media. If it continues to happen, then the purpose of learning to argue in social media can never be achieved with the result that many people will commit unlawful acts in social media. Therefore, it takes an activity that can lead students to be wise in arguing. A condition in the low ability to argue in social media as experienced by 20 students aged 15-18 in Demak (From MGBK Demak). Students feel not knowing the ethics convey the idea in social media, confused addressing information in the social media and easily provoked mediated social provocation. Low ability to argue in social media on students cannot be left alone, because if left students will have problems during speech in violation of the rules of social media and result in criminal penalties. Counseling is an effort of assistance provided by the supervising teacher to students who use the procedures, methods and materials to individual members to argue in social media. Communication is important in the formation of individual personality. With the individual communication can have a good life in the family, school and community, including in social media. Efforts to improve the ability of students to argue in social media can be done by organizing activities of individual counseling services. These activities address topics that are being experienced, give advice and ideas, respond, communicate with each other create the dynamics to develop themselves are practicing argue or express the opinions of the counselee.

The purpose of this study is individual counseling services are expected to effectively improve the ability to argue 20 students aged 15-18 in Demak. According to Prayitno, E. A. (2004), argues that individual counseling services (individual) is a special service in direct face to face relationship between counselor and client, in a relationship that is a problem the students themselves. This can be realized with the improvement and refinement. Willis (2004) adds that the notion of individual counseling services is the assistance provided by the counselor to a student with the goal of developing students' potential, able to cope with its own problems, and can adapt positively. Counseling is very important to help the child in the process of development and growth. Counseling can help children to be eradicated so that children will live more independently and happy.

Individual counseling services appropriate to be used as a form of counseling services and counseling to be given to students who have ability to argue in social media is still low. Counseling is not only face to face (FTF), counseling can be done with online counseling, online counseling can be used to help 
clients who cannot meet with a counselor because of the distance difference. With online counseling then counseling can be done anywhere and anytime (Ifdil, I. 2013). So expect optimally students can change and achieve positive improvement after participating in individual counseling activities. Students who participated in individual counseling can directly create a dynamic private practice doing exercises argue, respond to, listen to and to feel. This event is a place to develop them self in order to learn to argue in a positive and effective. This is reinforced by a study that found that individual counseling effectively alleviates the problems of students experiencing aggressive behavior in both the real world and the virtual world so it is expected that schools can provide individual counseling to students who have aggressive behavior. (Restu, Y. 2013).

\section{Method}

This study uses quasi experimental methods Experimental quay is a method by using a control class to compare with the same experimental class in the given treatment. Experiment class then analyzed to find the level of significance (Coolican, H., 1990; Howell, D. C., 2012). The final goal of this study was to determine the effectiveness of individual counseling to improve their skills in argumentation rest of the social media. Here, researchers used an quasi experimental method by comparing the full class in the given individual counseling services (experimental class) with classes that are not given individual counseling services (grade control). The researchers used a total population of respondents as many as 20 respondent Researchers provide individual counseling 10 times against respondent. The study was conducted by a counselor for one semester with one hour of counseling. According Arikunto (2002) a data analysis technique is a method used to process research data to obtain a conclusion. Technical data used to determine the effect of individual counseling services for student who have a less argumentation skills. Mechanical t test was used to test the significant differences in means. This research is to test whether individual counseling has significant influence to the skill of argument in social media or individual counseling has no significant effect on argumentation skill in social media.

\section{Results and Discussion}

Based on the results of t-test with significance level of $5 \%$ shows $t=7.017>$ table $=2.179$. Thus, means Ho accepted and rejected so that it can be said that the ability to argue in social media 20 students in Demak increased after being given individual counseling services, Based on the pre-test results, obtained data showing that there are some students have low scores. The research data 10 student

Figure 1.1 Graph Acquisition Total Score Initial Evaluation and Final Evaluation 10 student (experimental group)

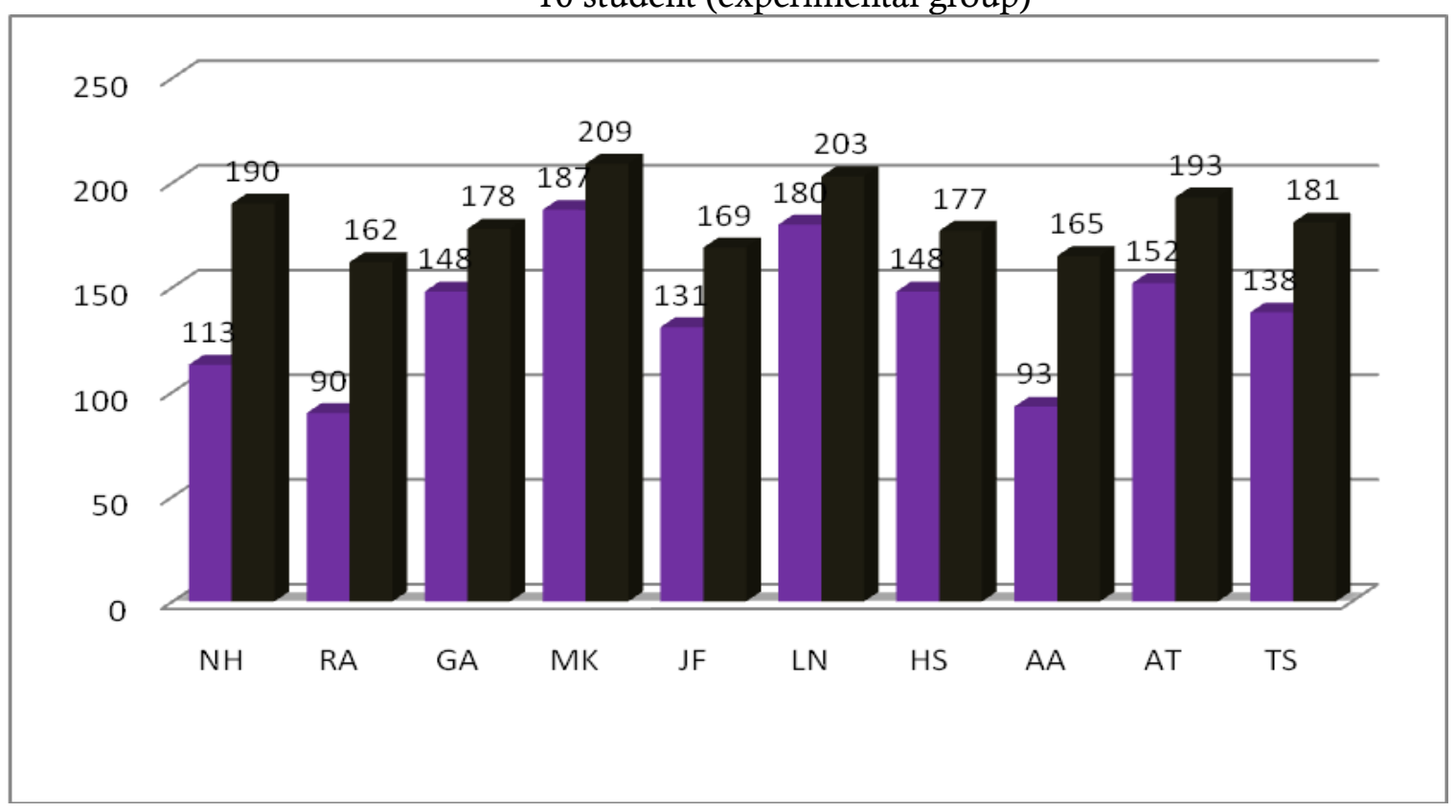


Tabel 1.2 Acquisition Total Score Initial Evaluation and Final Evaluation Argumentation Level 10 student (experimental group)

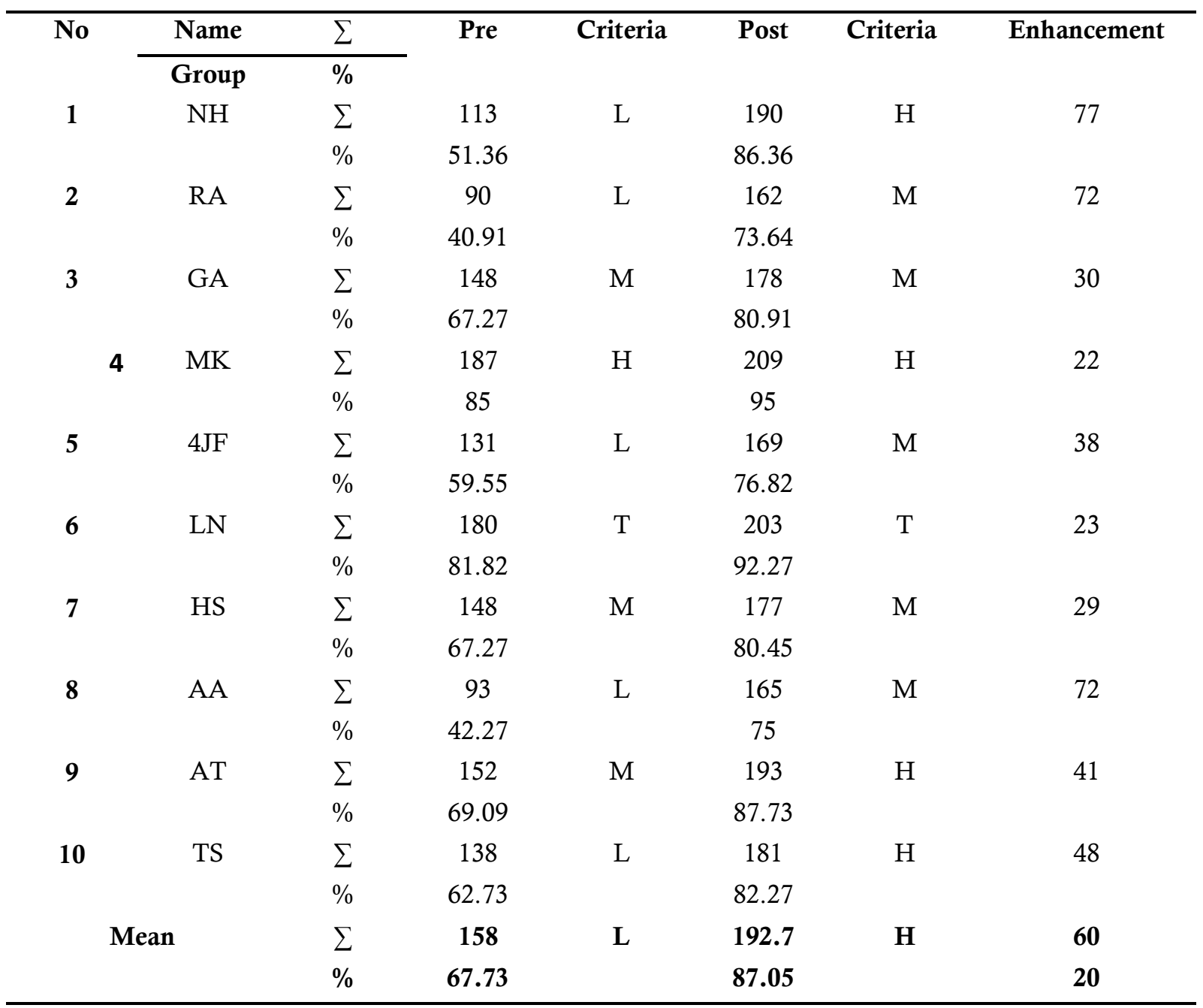

$\begin{array}{ll}\text { Criteria } & \\ \text { Height } & : \text { over } 180 \\ \text { Medium } & : 160 \text { to } 180 \\ \text { Low } & : \text { less } 160\end{array}$

For this reason, researchers are working to develop the ability to argue through individual counseling services. The counseling process is a systematic process that is carried out by counselors and clients to solve client problems. There are stages that must be passed to get on achieving a successful counseling. But before entering that stage the counselor should obtain data regarding the client's self through a preliminary interview (intake interview). This is reinforced by research that found that individual counseling is effective in modifying the behavior of junior high school children so that individual counseling is expected to help children live according to school and community rules (Serketich, W. J., \& Dumas, J. E. 1996; MacArthur, J. F., \& Mack, W. A. 2017).

Individual counseling is effective in improving students' ability to argue, because of the activities of individual counseling that students are encouraged to practice argue. Of these students will gain a variety of experiences, knowledge and ideas. Students can learn to develop values and implement joint measures to reach the topics covered in individual counseling. The result showed that an increase in the development of the ability to argue between before and after individual counseling. Data pre-test of 20 
students showed the ability to argue that low and fairly. At the end of the activity, the study provides post-test. Post-test results showed an increase in average scores on the respondent's ability to argue. Researchers in an effort to test whether there significant using t-test with significance level of $5 \%$ shows $t$ $=7.077>$ table $=2.179$. Based on the results of these calculations, shows that ability to argue students increased after being given individual counseling services.

Based on the analysis of research data it is said that the treatment of individual counseling that is done is a kind of effective services, especially for students. This is because the study subjects after receiving individual counseling, based on data obtained showed an increased ability to argue with an average increase significantly. Increased ability to argue was marked by students who originally easily ignited emotions while reading news hoax, made a status which leads to SARA and use the word dirty word in response to the phenomenon of social media has changed into selective in responding to a message, and using words that are polite in making social media posts. In a research report prepared to explain that individual counseling is very effective in giving the views and character so that students have ethics in communicating in social media. (Hulukati, W.2013). The counseling process is done with individual counseling methods with techniques RABT. Counseling performed 10 times with a pretest and posttest. Effective and efficient helping skills produce a variety of behaviors, techniques, and practices that match the theoretical and philosophical point of view of the counselor. Successful counselors improve arguing skills to adapt in choosing and developing strategies that bring their theoretical credentials that are appropriate to them and their clients. The benchmark for effective counselors in this regard is the ability to select tendencies in a particular theory, to cultivate them to fit the unique perspective and beliefs of each person, and to have the communication and facilitation skills required to use those views and assumptions to help him and Others achieve optimum development (Schmidt, J.J. 2008). School counselors should be sensitive to the problem of arguing in this social media because this is very important.

The counseling profession gets its name from a function that explains and describes the main role of its members. The cornerstone of all services provided by professional counselors is knowledge of the theory of counseling and the use of effective helping skills. So, understanding, attitude, and skills of counselor in implementing strategy and intervention as core of counselor success in increasing skill of argue social media. The counseling profession has been discussing, explaining, debating, and working on counseling. The term counseling has been extensively defined in various professional literatures, but this effort does not always result in a consistent definition.

On the one hand, this inconsistency is due to the various places where the counselor practices one of the many theories on which the definitions are based. The contemporary definition of counseling illustrates that the profession focuses on the breadth of human needs, including the prevention, development and healing relationships. Pietrofesa, Hoffman, and Splete (in Schmidt, 2008) describe counseling as a process facilitated by a professional for someone who "seeks help in achieving better selfknowledge, better decision making, and behavioral change skills for problem solving and / Or growth progress ". Nugent (in Schmidt, 2008) mimics that point of view by saying, "Wherever they work, counselors help people, families and groups solve conflicts, overcome problems, or make decisions in social and cultural contexts."

By building a broader goal for helping relationships, counselors offer services to a wide range of people who are actually healthy and able to move. Among these groups some people have psychological and social problems, others seek information and support for self-development decisions they will make in the future. Gladding (in Schmidt, 2008) abbreviates these elements by defining counseling as a brief relationship formed on one or more theoretical models to assist relatively healthy people to make decisions in their lives.

Individual counseling since the early days of the counseling movement has been defined as a core activity in which all other activities are effective. Counseling is a one-to-one relation that focuses on personal growth and adjustment, and meets the need for problem solving and decision making needs. The assistance is a client-centered process that demands the trust of the counselor and the client's trust in him. This process begins when a condition of contact or psychological relation is formed between counselor and client; It will move forward when certain conditions essential to the success of the counseling process are met. Many practitioners believe these essential conditions include such things as sincerity and counselor congruence, respect for clients and an empathetic understanding of the client's internal frame of reference (Gibson \& Mitchell, 2011). School is the specific place where the counseling process is practiced. As with other professional venues, the primary mission of the school coloring school practices focuses on the educational goals of students, parents and teachers. Therefore, counseling in 
schools is a process to help students, parents and teachers learn about themselves; Understand how their personal characteristics, human potential, and how behavior affects their relationships with others; And make decisions to solve problems encountered and plan strategies for optimal growth. Using the broad definition, school counselors' access to students, parents and teachers will benefit from counseling relationships, and indicate whether they are the best professionals who provide services for this group (Schmidt, 2008).

Counseling is a process. Counseling has a beginning. Counseling is characterized by a series of steps and stages, and will end when the goal is met. As well as the abundance of theories about counseling, there are many choices of models of help-help to choose from (Stone \& Dahir in Schmidt, 2008). By having an effective model on which their counseling relationship relies, it allows counselors to organize and demonstrate effective aid processes. In schools with young students, structure and direction is a precise, steady step in counseling relationships. Counseling models range from three to many stages. The following will explain the four-stage approach to the counseling process. A stage that offers counselors a design to build effective relationships, where these stages help school counselors stay alongside and consistently encourage students and other clients to move closer to their identified objectives.

Counseling is the process of expressing expectations, desires, concerns, fears, and failures in changing behavior, changing external factors, and setting future goals. Close and communicative relationships are only possible if they are based on positive acceptance, understanding and appreciation. Counselors show empathetic understanding as they accurately perceive the client's world, being able to see things in the client's eyes, and the ability to verbally communicate that understanding back to the client. Respect is another equally important point from the first stage of relationship in counseling. Respect here means equality, justice, and shared responsibility (Schmidt, J.J. 2008). In counseling, nothing is more important than the people in it, therefore counseling recognizes the rich complexity and unique value of every human being. In school, the condition of respecting one's worth is very important as a successful effort to help establish relationships with students.

School counselors should show their liveliness and appear to be authoritative, firmly held, accountable, and worthy of respect. It is not easy to achieve. Counselors who practice honor, act cautiously, and show the highest levels of professional performance are able to win the respect of students, parents, and teachers. On the other hand, counselors who neglect their duties, divulge secrets, behave without acceptance, use mockery, and defame education and counseling professions mean showing disrespect for themselves and others (Schmidt, J.J. 2008). The result is always avoided by students, parents, and teachers.

Authenticity is concerned with respect. Counselors who can accept others can also express their true feelings and react to the concerns expressed by their clients. At the same time, the original counselor shows the same consistent behavior between what they say and what they do (Schmidt, J.J. 2008). Authenticity is sometimes called congruence, a condition that reflects honesty, transparency and openness to the client. This congruence arises from respecting the client relationship. Another important thing in the relationship, is the ability of the counselor to reveal themselves, the ability to express thoughts, opinions, and feelings after the awareness or understanding of what the client disclosed. This self-disclosure is very important to let the client understand that the counselor is a person, not just a role. Thus this ability should be used appropriately during the counseling process.

\section{Conclusion}

Individual counseling services are effective in improving students' ability to argue in social media include sage in response to a phenomenon in social media, using polite language in response to a phenomenon and adults in the act on social media. It is shown from changes in the behavior of students at each meeting individual counseling has led to an increase in the ability to argue in social media better than ever. Additionally known from the results of data analysis showed that $t$ is greater than $t$ table.

\section{Acknowledgment}

I thank the stakeholders in the District of Demak, Demak teachers, lecturers and friends student that I love. I would like to thank friends in arms, guidance and counseling teacher who never tired of helping solve student's problems. I dedicate this to friends so that we can reduce children who commit negative actions in social media. Hopefully in the future I can help with future research studies related to the advancement of the students Indonesia 


\section{References}

Andrews, F. M., \& Withey, S. B. (2012). Social indicators of well-being: Americans' perceptions of life quality. Springer Science \& Business Media.

Arfitriani, Y. N. (2010). Upaya Meningkatkan Kepercayaan Diri Pada Siswa Broken Home Melalui Konseling Individual Dengan Pendekatan Realita.

Arikunto, Suharsimi. (2002). Prosedur Penelitian Suatu Pendekatan dan Praktik. Jakarta: Rineka Cipta.

Coolican, H. (1990). Research methods and statistics in psychology. Hodder \& Stoughton Educational.

Gibson, R.L. \& Mitchell, M.H. 2011. Bimbingan dan Konseling. Yogyakarta: Pustaka Pelajar.

Howell, D. C. (2012). Statistical methods for psychology. Cengage Learning.

Hulukati, W. (2013). The improvement of teacher competencies in guidance and counseling for the development of students personality. Indian Journal of Positive Psychology, 4 (3), 396.

Ifdil, I. (2013). Konseling Online Sebagai Salah Satu Bentuk Pelayanan E-konseling. Jurnal Konseling dan Pendidikan, 1(1), 15-22.

Katz, J., Capron, A. M., \& Glass, E. S. (1972). Experimentation with human beings: The authority of the investigator, subject, professions, and state in the human experimentation process. Russell Sage Foundation.

Keraf, Gorys. (1981). Argumentasi dan Narasi (Komposisi Lanjutan III). Jakarta: PT GramediPustaka Utama.

Keyes, C. L. M. (1998). Social well-being. Social psychology quarterly, 121-140.

MacArthur, J. F., \& Mack, W. A. (2017). Counseling: How to Counsel Biblically. HarperCollins Christian Publishing.

Prayitno, E. A. (2004). Dasar-dasar Bimbingan dan Konseling. Jakarta: Rineka Cipta.

Restu, Y. (2013). Studi Tentang Perilaku Agresif Siswa di Sekolah. Konselor, 2(1).

Schmidt, J.J. (2008). Counseling in School. New York: Pearson.

Serketich, W. J., \& Dumas, J. E. (1996). The effectiveness of behavioral parent training to modify antisocial behavior in children: A meta-analysis. Behavior therapy, 27(2), 171-186.

Shanty, R. M. N., \& Christiana, E. (2013). Pelaksanaan Layanan Konseling Individudi SMPN SeKecamatan Bangsal Mojokerto. Jurnal BK UNESA, 3(1), 388-393.

Soffyan S. Wilis. (2004). Konseling Individual Teori dan Praktek. Bandung: Alfabeta.

Surat Edaran Kapolri SE/06/X/2015.

Weston, Anthony. (2007). Kaidah Berargumentasi. Yogyakarta: Pustaka Pelajar. 